\title{
Reaction of Cucurbit Species to Squash Leaf Curl Virus and Sweetpotato Whitefly
}

\author{
James D. McCreight \\ U.S. Agricultural Research Station, Agricultural Research Service, U.S. Department of Agriculture, \\ 1636 East Alisal Street, Salinas, CA 93905
}

\begin{abstract}
Albert N. Kishaba ${ }^{1}$
Boyden Entomology Laboratory, Agricultural Research Service, U.S. Department of Agriculture, University of California, Riverside, CA 92521

Additional index words. Benincasa hispida, Cucurbita ecuadorensis, C. foetidissima, C. ficifolia, C. lundelliana, C. martinezii, C. maxima, C. mixta, C. moschata, C. pepo, C. texana, Lagenaria siceraria, Luffs acutangula, Luffs aegyptiaca, Lufa graveolens, marrow, pumpkin, Bemisia tabaci, whitefly, tobacco whitefly, disease resistance
\end{abstract}

\begin{abstract}
Squash leaf curl (SLC) is a virus disease of squash transmitted by the sweetpotato whitefly [Bernisia tabaci (Germ.)]. 'Cucurbita maxima Duch. ex Lam., $C$. mixta Pang, and $C$. pepo L. cultivars and the wild taxon. $C$. texana Gray exhibited severe symptoms in response to SLC in greenhouse and field tests. Symptoms on $C$. moschata (Duch.) Duch. ex Poir. cultivars were much more severe in greenhouse tests than in field tests. Three wild species, $C$. ecuadorensis Cutler and Whitaker, $C$. lundelliana Bailey, and $C$. martinezii Bailey, were virtually immune in greenhouse tests, but were infected in field tests. Cucurbita foetidissima HBK expressed moderate symptoms in a field test. Benincasa hispida (Thunb.) Cogn., C. ficifolia Bouche, Lagenaria siceraria (Mol.) Standl., Luffa acutangula (L.) Roxb., Luffs aegyptiaca Mill., and Luffs graveolens Roxb. were resistant to SLC in greenhouse and field tests.
\end{abstract}

Squash leaf curl (SLC) is a virus disease of squash transmitted by the sweetpotato whitefly in the lower deserts of Arizona, California, and northern Mexico (Flock and Mayhew, 1981). SLC has virtually eliminated fall squash production in Imperial Valley, Calif. (F. Laemmlen, personal communication).

SLC reached epidemic proportions in Fall 1981 and is now endemic to squash production throughout the southwestern United States and Mexico. The cultivar Mediterranean (Cucurbita moschata), grown commercially only in Imperial Valley, was considered to be resistant to SLC until the 1981 epidemic, when it developed SLC symptoms and had reduced yield. Compared with the vegetative symptoms and yield loss of cultivars of $C$. maxima, C. mixta, and C. pepo, 'Mediterranean' has a high level of tolerance to SLC.

Because of the infectious nature and wide host range of SLC (Cohen et al., 1984; Flock and Mayhew, 1981) and the wide host range (Azab et al., 1970; Pollard, 1955; Varma, 1963), fecundity (Butler et al., 1983, 1985; Gerling, 1967; Husain and Trehan, 1933; Zalom et al., 1985), and insecticide resistance (Commonwealth Inst. for Biological Control, 1981; Toscano et al., 1985) of the sweetpotato whitefly, host-plant resistance must be considered for reducing losses to SLC. Our objectives were four-fold: 1) to evaluate for resistance to SLC in a large sample of the four Cucurbita species (C. maxima, C. mixta, $C$. moschata, and $C$. pepo) that are widely cultivated in the United States; 2) to evaluate four closely related wild species of $\mathrm{Cu}$ curbita for their potential as sources of resistance to SLC; 3) to determine the potential threat of SLC to eight wild and regionally important cucurbit species; and 4) to determine the relative

Received for publication 3 Oct. 1989. We gratefully acknowledge the assistance of A.V. Duran, J.H. Foreman, J.A. Principe, and S.A. Castle in greenhouse and field tests, H.Y. Liu for the squash leaf curl virus isolate and assistance in ELISA tests, B.E. Mackey for statistical assistance, and H.M. Munger and T.W. Whitaker for helpful suggestions. The cost of publishing this paper was defrayed in part by the payment of page charges. Under postal regulations, this paper therefore must be hereby marked advertisement solely to indicate this fact.

'Present address: Subtropical Research Laboratory, Agricultural Research Service, U.S. Dept. of Agriculture, P.O. Box 267, Weslaco, TX 78596. suitability of these cucurbits as hosts for the sweetpotato whitefly.

\section{Materials and Methods}

Cultivars of $C$. maxima, C. mixta, C. moschata, C. pepo, and accessions of four of their wild relatives, $C$. ecuadorensis, C. lundelliana, C. martinezii, and C. texana, were tested for reaction to SLC virus in greenhouse and field tests. Cucurbita foetidissima was also tested because of its potential importance as an oilseed and starch crop in the southwestern United States (Bemis et al., 1978). Collections of Benincasa hispida, C. ficifolia, C. texana, Lagenaria sicerana, Lufla acutangula, Luffs aeuptiaca, and Lufla graveolens were tested in field tests. Whitefly reproduction was studied in field tests.

Greenhouse tests. Seeds were planted in sand in 0.7-liter pots and watered with a 1 nutrient solution : 300 water dilution of standard Hewitt nutrient solution as modified by Ward (1973), but with micronutrients diluted to one-fifth the recommended concentration. There were five inoculated and five control plants of each squash cultivar tested. 'Pink Banana' or 'Gray Banana' (C. maxima) was included as a susceptible control in every test.

Plants were inoculated with SLC virus at the one to two trueleaf stage of growth, using B. tabaci as the vector. The SLC isolate used was collected in 1981 from a single plant in a naturally infected commercial field of $C$. pepo in Imperial Valley and purified as described by Cohen et al. (1984). Whiteflies were transferred from healthy sweetpotato [Ipomoea batatas (L.) Lam.] to detached, SLC virus-infected squash leaves placed in water to maintain turgor and encourage feeding. After a 24-h acquisition time, 10 viruliferous whiteflies were transferred via pipette into cages on individual test plants.

In early tests, the cotyledons and, in some tests, first true leaves were removed before placing a clear plastic sleeve-cage [closed at one end with 48 -mesh nylon cloth $(\approx 19$ threads $/ \mathrm{cm})$ ] over each plant. After a 48 - to 72 -h feeding time, the plants were sprayed with resmethrin before and after removing the cages to kill the whiteflies.

In later tests, 10 viruliferous whiteflies were placed in polyfoam leaf-cages identical to those used by Kishaba et al. (1976), 
but modified with a $25 \times 30$-mm-diameter clear plastic vial attached to the polyfoam collar on one arm of each cage. The open ends of the vial were covered with 86-mesh nylon cloth ( $\approx 34$ threads/cm) through which the whiteflies could feed and oviposit. The cages (one cage per plant) were placed so that one end of the vial was on the underside of the leaf, where whiteflies normally feed and oviposit. Duration of feeding was the same as with the sleeve-cages. At the end of the feeding time; the cages were removed from the plants. In the first tests with the leaf-cages, $87 \mathrm{~g}$ of Temik granules per plant were mixed with sand and spread around the base of the stem to kill offspring from the-eggs laid during feeding. In later tests, the entire inoculated leaf was removed from the plant 5 days after cage removal.

Symptoms were visible 10 to 14 days after inoculation. Symptoms were evaluated on a 1 (symptomless) to 9 (dead) scale 14 to 21 days after initial whitefly feeding.

Field test with transplants. This test was done to determine if the reactions of $C$. ecuadorensis, C. ficifolia, C. lundelliana, and $C$. martinezii to controlled inoculations in the greenhouse in 1983 and 1984 were indicative of their performance under field conditions. From each of the test plants, three plants were vegetatively propagated in a greenhouse by layering shoot tips in sand and transplanted to the field at Brawley, Calif., on 24 July 1984. The number of mother plants of each accession ranged from six to 31 . Thus, the number of transplants per wild accession ranged from 18 to 93 . The number of wild accession transplants that survived until the first SLC evaluation ranged from one to 81 .

Five cultivars of the foul cultivated species were included in the test for comparison. They were propagated from seed in the greenhouse and transplanted with the wild accessions. The number of plants of each cultivar ranged from nine to 27 . The number of transplants of each cultivar that survived until the first SLC evaluation ranged from zero to 12 .

There was a total of 210 transplants in each of three replications. Transplants were spaced $1.5 \mathrm{~m}$ within and $2.0 \mathrm{~m}$ between beds. They were watered when transplanted and furrowirrigated immediately following completion of the transplanting operation. Daytime temperatures at time of transplanting exceeded 40C. SLC symptoms were evaluated using the same scale as in the greenhouse tests.

A preliminary study in 1983 (unpublished data) indicated potentially useful differences among several cucurbits for suitability as sweetpotato whitefly hosts. To further study this possibility, three old and three young leaves were sampled from each plant. Area of each leaf was estimated using a $1.27-\mathrm{cm}^{2}$ grid. Separate counts of eggs, small larvae, medium larvae, large larvae, pupae, and pupal skins were made on each leaf sampled. All the data from old and young leaves were combined for each plant. Using these totals, plants were classified as low, medium, and high for whitefly counts. Leaf samples from selected (low, medium, and high) plants of $C$. ecuadorensis, $C$. ficifolia, $C$. lundelliana, and $C$. martinezii were collected from the remaining two replications. These samples were measured and counted as described above. Paired (by plant) t tests were done to determine if counts significantly differed between young and old leaves. Analyses of variance were done on counts of each whitefly growth stage by leaf age, on total counts by leaf age, and on the combined total of counts from young and old leaves. Analyses were done on whole-leaf and unit $\left(\mathrm{cm}^{2}\right)$ of leaf area bases.

Field test with seeds. Cultivars, breeding lines, and acces- sions of 12 species of Cucurbitaceae were planted at Brawley; 151 entries were planted and watered on 26 July and an additional 12 entries were planted into moisture on 31 July. Plots consisted of two hills spaced $1.5 \mathrm{~m}$ apart; three to four seeds were planted per hill and thinned to two plants per hill. Plots were spaced $3 \mathrm{~m}$ within and $2 \mathrm{~m}$ between beds. SLC symptoms were evaluated using the same scale as in the greenhouse tests.

Enzyme-linked immunosorbent assay (ELISA). SLC virus infection was verified in all tests using the procedures of Cohen et al. (1984).

\section{Results}

Greenhouse tests. Symptom ratings of the 76 C. maxima, $C$. mixta, C. moschata, and $C$. pepo cultivars ranged from 5.0 to 8.0 (Table 1). Mean symptom rating was 8.0 for 53 cultivars; 7.0 for 13 ' cultivars; 6.0 for six cultivars; and 5.0 for two of them.

Some cultivars of $C$. moschata and $C$. pepo appeared to recover from SLC 3 to 4 weeks after inoculation. For example, 14 days after inoculation, 'Black Magic' ( $C$. pepo) had a symptom rating of 8.0 , but had a 4.0 rating 17 days later. The infected 'Black Magic' plants were comparable in size to the control plants and were flowering and setting fruit with the same frequency as noninoculated plants. The other four cultivars in the test with 'Black Magic' did not recover.

Cucurbita ecuadorensis, C. lundelliana, and C. martinezii were all rated 1.0 in two separate greenhouse tests (Table 1). A single plant of C. martinezii, which appeared to be infected with SLC virus, had a negative ELISA test.

Field test with transplants. The data from this test contrasted markedly with those for the greenhouse. Mean symptom ratings of the four widely cultivated species (maxima, mixta, moschata, and реро) on 27 Aug. (5 weeks after transplanting) were milder than in the greenhouse tests and ranged from 2.7 to 6.2 (Table $2)$. On 4 Oct. (10 weeks after transplanting), mean symptom ratings ranged from 2.7 to 6.0 (data not shown). 'Mediterranean' (C. moschata) and 'Tatume' (C. pepo) were remarkable because their symptoms remained relatively unchanged from August through October.

Cucurbita ecuadorensis, C. lundelliana, and C. martinezii were susceptible in the field test with transplants. In August, symptoms were mildest on $C$. lundelliana; mean symptom ratings for the three accessions ranged from 1.8 to 3.1 (Table 2). "Mean symptom ratings on $C$. ecuadorensis and $C$. martinezii ranged from 5.0 to 5.7. By October, symptoms on $C$. lundelliana and $C$. ecuadorensis were more pronounced, but little change was noted on $C$. martinezii (data not shown).

The $C$. ficifolia accessions were either symptomless or had

Table 1. Mean squash leaf curl symptom rating on seven Cucurbita spp. in greenhouse tests.

\begin{tabular}{lccc}
\hline \hline & & \multicolumn{2}{c}{ Symptom rating } \\
\cline { 3 - 4 } \multicolumn{1}{c}{ Species } & No. entries & $\overline{\mathrm{x}}$ & Range \\
\hline ecuadorensis & 1 & 1.0 & $1.0-1.0$ \\
lundelliana & 3 & 1.0 & $1.0-1.0$ \\
martinezii & 2 & 1.0 & $1.0-1.0$ \\
maxima & 15 & 7.8 & $7.0-8.0$ \\
mixta & 3 & 7.7 & $7.0-8.0$ \\
moschata & 11 & 6.8 & $5.0-8.0$ \\
pepo & 47 & 7.6 & $6.0-8.0$ \\
\hline
\end{tabular}

${ }^{2}$ Rated on a 1 (symptomless) to 9 (dead) scale. 
Table 2. Squash leaf curl symptom ratings (mean and range) on three wild and five cultivated species of Cucurbita in a naturally infected field test with transplants.

\begin{tabular}{|c|c|c|c|c|}
\hline \multirow[b]{2}{*}{ Species } & \multirow[b]{2}{*}{ Entry } & \multirow{2}{*}{$\begin{array}{l}\text { No. } \\
\text { plants }\end{array}$} & \multicolumn{2}{|c|}{ Symptom rating ${ }^{x}$} \\
\hline & & & $\overline{\mathbf{x}}$ & - Range \\
\hline ecuadorensis & PI 540895 & 69 & $5.0 \mathrm{ehi}$ & $1.0-9$ \\
\hline \multirow[t]{3}{*}{ ficifolia } & PI 540901 & 3 & 3.0 acdef & $1.0-5.0$ \\
\hline & Ibarray & 1 & $1.0 \mathrm{a}$ & $1.0-1$ \\
\hline & Oaxaca ${ }^{y}$ & 1 & $1.0 \mathrm{a}$ & $1.0-1$ \\
\hline \multirow[t]{3}{*}{ lundelliana } & PI 540896 & 73 & $2.7 \mathrm{~cd}$ & $1.0-7$. \\
\hline & PI 540897 & 70 & $1.8 \mathrm{ab}$ & $1.0-7.0$ \\
\hline & PI 540898 & 81 & 3.1 defg & $1.0-7.0$ \\
\hline \multirow[t]{2}{*}{ martinezii } & PI 540899 & 76 & $5.7 \mathrm{ij}$ & $1.0-8.0$ \\
\hline & PI 540900 & 61 & $5.4 \mathrm{ij}$ & $1.0-8.0$ \\
\hline maxima & Gray Banana & 7 & $6.2 \mathrm{hj}$ & $4.0-8.0$ \\
\hline mixta & Japanese Pie & 2 & 5.0 aehij & $3.0-7.0$ \\
\hline moschata & Mediterranean & 4 & $4.2 \mathrm{acefh}$ & $2.0-6.0$ \\
\hline \multirow[t]{2}{*}{ реро } & Black Magic & 5 & $3.0 \mathrm{abc}$ & $2.0-4.0$ \\
\hline & Tatume & 12 & 2.7 acde & $1.0-7.0$ \\
\hline
\end{tabular}

${ }^{2}$ Rated on a 1 (symptomless) to 9 (dead) scale. Mean separation by $\mathrm{LSD}_{0.01}$. Large differences in the number of plants per mean among entries resulted in seemingly contradictory significant and nonsignificant differences of identical or similar mean values relative to other mean values, i.e., entries $C$. mixta 'Japanese Pie' and $C$. ecuadorensis entry PI 540895.

${ }^{y}$ PI number pending.

only mild symptoms; however, survival rate following transplanting was low for this species (Table 2).

"ELISA tests confirmed. SLC virus infection in the wild and cultivated entries. There was no relationship between virus titer, as measured by ELISA and symptom rating. There were numerous $C$. lundelliana plants without any apparent SLC symptoms that had ELISA values as high as those with severe symptoms.

Paired (by plant) $t$ tests for differences in number of whitefly eggs, lamae, pupae, or pupal cases, or total of all growth stages per leaf and pe runit area between old and young leaves on the plants classified low, medium, and high were significant $\left(\mathrm{t}_{0.01}\right)$. Differences among plants for total of all growth stages per leaf and per unit area of leaf were significant on young $\left(\mathrm{P}_{0.01}\right)$ and old $\left(\mathrm{P}_{005}\right)$ leaves (Table 3$)$. Because of severe stunting or mortality at the time of whitefly sampling in the second and third replications (23 Oct.), the cultivated Cucurbita could not be included.

One C. lundelliana plant (P1 540897,plant number 65)had the fewest whiteflies per unit area on young and old leaves. A C. martinezii plant (PI 540900, plant number 60) had the highest number of whiteflies per unit area on young and old leaves (Table 3).

Correlations between symptom severity and total of all whitefly growth stages per unit area on young and old leaves were significant $\left(\mathrm{P}_{0.001}\right) ; 0.26$ and 0.30 , respectively.

Field test with seeds. All entries of the four cultivated $\mathrm{Cu}$ curbita spp. were susceptible in the field test (Table 4). Mean symptom ratings by species were: C. maxima, 7.2; C. pepo, 6.4; C. mixta, 5.7; and $C$. moschata, 4.1. Mean symptom expression among cultivars of each species did not vary greatly (Table 4). Considerable variation was observed, however, among plants within one or more cultivars of each species.

The single accession of $C$. texana was susceptible (Table 5). Two accessions of $C$. ficifolia were susceptible, but the accession from Ibarra, Ecuador, was resistant. Cucurbita foetidissima accessions in the test were also susceptible. Cucurbit species of
Table3. Mean number of sweetpotato whiteflies (Bemisia tabaci) per square centimeter of leaf of three wild Cucurbita spp. infected with squash leaf curl virus.

\begin{tabular}{crrrr}
\hline $\begin{array}{c}\text { Species and } \\
\text { collection }\end{array}$ & $\begin{array}{c}\text { Plant } \\
\text { no. }\end{array}$ & $\mathrm{n}^{\mathrm{y}}$ & $\begin{array}{c}\text { Young } \\
\text { leaves }\end{array}$ & $\begin{array}{c}\text { Old } \\
\text { leaves }\end{array}$ \\
\hline $\begin{array}{c}\text { ecuadorensis } \\
\text { PI 540895 }\end{array}$ & 79 & 3 & 17.7 & 16.8 \\
& 83 & 2 & 12.1 & 24.0 \\
& 183 & 3 & 13.4 & 35.8 \\
lundelliana & & & & \\
PI 540896 & 39 & 2 & 15.7 & 11.9 \\
& 56 & 3 & 29.6 & 14.8 \\
PI 540897 & 76 & 3 & 11.3 & 4.0 \\
PI 540898 & 61 & 2 & 12.0 & 9.3 \\
& 2 & 3 & 8.3 & 7.4 \\
& 7 & 3 & 20.5 & 8.8 \\
& 65 & 3 & 5.4 & 0.8 \\
& 92 & 2 & -20.3 & 3.7 \\
& 127 & 2 & 48.2 & 8.4 \\
PI 540899 & 129 & 2 & 16.1 & 15.2 \\
PI 540900 & 163 & 3 & 9.9 & 5.8 \\
& 149 & 2 & 22.0 & 44.8 \\
& 32 & 2 & 26.0 & 34.9 \\
\hline
\end{tabular}

${ }^{\mathrm{z}}$ Includes eggs, larvae, pupae, and cast skins.

${ }^{y} n=$ Number plots sampled; one leaf was taken from each of three plants. Values were extrapolated from counts made on $=20 \%$ of the leaf area.

regional importance were mostly resistant to SLC. The single accession of $B$. hispida was resistant. Nine of 11 Lagenaria siceraria accessions were resistant. Five accessions of three Luffa spp. were resistant.

\section{Discussion}

All cultivars of the four cultivated Cucurbita species were susceptible to SLC in greenhouse and field tests. Symptom expression on these four cultivated species was more severe and uniform in the greenhouse than in the field test with seeds. The discrepancy between the greenhouse and field tests could have been an artifact of growing the plants in 0.7-liter pots in the greenhouse. Roots are not restricted to a finite volume in the field. Cucurbits have extensive root systems (Whitaker and Davis, 1962); restricted root development could result in a more severe reaction to viral infection. This limitation would be especially important in the reaction of cultivars with indeterminate, vinetype growth habits.

Symptom expression in the greenhouse tests was generally more uniform than in the field. For example, symptom ratings on 'Buttercup Burgess' (C. maxima) ranged from 1.0 to 8.0 in the field test, but all five plants inoculated in the greenhouse were rated 7.0. The $C$. moschata cultivars are possible exceptions. Symptom expression on 'Mediterranean' ranged from 1.0 to 7.0 in the field and from 4.0 to 7.0 in the greenhouse.

In contrast to the four cultivated species, $C$. ecuadorensis, C. lundelliana, and C. martinezii were virtually symptomless in the greenhouse tests but developed symptoms in the field (Table 2). These data reflect vegetative symptoms and not the effect of SLC on fruit production. Despite the relatively mild symptoms, the cultivated species produced very few fruit in the field, whereas the three wild species flowered and produced numerous fruit. The discrepancy between the greenhouse and field tests could have been due to differences in the inoculation 
Table 4. Squash leaf curl symptom ratings (mean and range) on tour cultivated Cucurbita spp. in a naturally infected field test. ${ }^{2}$

\begin{tabular}{|c|c|c|c|}
\hline Species and entry & $\mathrm{n}^{\mathrm{y}}$ & $\overline{\mathbf{x}}$ & Range \\
\hline \multicolumn{4}{|l|}{$\overline{\operatorname{maxima}(\overline{\mathrm{x}}=7.2)}$} \\
\hline Big Max & 8 & 8.0 & $7.0-9.0$ \\
\hline Blue Hubbard & 12 & 7.0 & $5.0-8.0$ \\
\hline Boston Marrow Necky & 6 & 7.5 & $7.0-8.0$ \\
\hline Buttercup & 18 & 7.4 & $6.0-9.0$ \\
\hline Buttercup Burgess & 9 & 5.6 & $1.0-8.0$ \\
\hline Chicago Warted Hubbard & 12 & 7.2 & $7.0-8.0$ \\
\hline Golden Delicious & 9 & 7.2 & $6.0-8.0$ \\
\hline Green Delicious & 11 & 7.5 & $7.0-8.0$ \\
\hline Imperial Green Hubbard & 11 & 7.4 & $6.0-8.0$ \\
\hline King of Mammoth & 10 & 6.4 & $5.0-7.0$ \\
\hline Mammoth Gold & 12 & 7.5 & $7.0-8.0$ \\
\hline Pink Banana Jumbo & 11 & 7.1 & $6.0-8.0$ \\
\hline True Hubbard & 11 & 7.8 & $7.0-9.0$ \\
\hline Yakima Marblehead & 10 & 6.9 & $5.0-8.0$ \\
\hline \multicolumn{4}{|l|}{$\operatorname{mixta}(\overline{\mathrm{x}}=5.7)$} \\
\hline Cushaw Green Striped & 8 & 6.4 & $5.0-7.0$ \\
\hline Golden Cushaw & 5 & 4.4 & $1.0-7.0$ \\
\hline Japanese Pie & 11 & 5.7 & $5.0-7.0$ \\
\hline \multicolumn{4}{|l|}{ moschata $(\overline{\mathrm{x}}=4.1)$} \\
\hline Amcobella & 10 & 6.4 & $5.0-7.0$ \\
\hline Amcobella 94 & 10 & 6.6 & $6.0-7.0$ \\
\hline Aquarius & 11 & 5.5 & $5.0-6.0$ \\
\hline Butterbush & 10 & 3.7 & $1.0-6.0$ \\
\hline Hercules & 7 & 3.3 & $1.0-7.0$ \\
\hline Hercules Butternut & 10 & 2.7 & $1.0-4.0$ \\
\hline Kentucky Field & 10 & 6.0 & $5.0-7.0$ \\
\hline Long Genoa Queen & 3 & 7.7 & $7.0-8.0$ \\
\hline Mediterranean & 10 , & 3.3 & $1.0-7.0$ \\
\hline PI 540904 & 11 & 2.7 & $1.0-6.0$ \\
\hline PI 540905 & 11 & 4.2 & $3.0-5.0$ \\
\hline PI 540906 & 10 & 5.5 & $4.0-6.0$ \\
\hline Ponca & 7 & 4.1 & $3.0-6.0$ \\
\hline Seminole Pumpkin & 8 & 4.9 & $3.0-6.0$ \\
\hline Waltham Butternut & 4 & 3.2 & $3.0-4.0$ \\
\hline \multicolumn{4}{|l|}{ pepo $(\overline{\mathbf{x}}=6.4)$} \\
\hline Bennings Green Tint & 20 & 7.2 & $6.0-8.0$ \\
\hline Black Beauty & 20 & 5.9 & $4.0-7.0$ \\
\hline Black Magic & 10 & 5.5 & $5.0-6.0$ \\
\hline Blackie $\mathrm{F}_{1}$ & 9 & 6.1 & $5.0-7.0$ \\
\hline Black Zucchini & 8 & 6.2 & $5.0-7.0$ \\
\hline Bush Tablequeen & 3 & 6.7 & $6.0-8.0$ \\
\hline Casablanca & 9 & 4.7 & $3.0-6.0$ \\
\hline Caserta & 3 & 5.0 & $1.0-7.0$ \\
\hline Caserta Br. & 12 & 6.4 & $5.0-7.0$ \\
\hline Caserta Bush & 12 & 5.1 & $1.0-7.0$ \\
\hline Cattleback & 10 & 6.4 & $5.0-7.0$ \\
\hline Chefini & 9 & 6.0 & $5.0-7.0$ \\
\hline Cocozelle & 12 & 6.5 & $6.0-8.0$ \\
\hline Cocozelle Long Type & 12 & 6.7 & $6.0-7.0$ \\
\hline Connecticut Field & 10 & 7.0 & $4.0-8.0$ \\
\hline Corsair X1391 & 9 & 5.0 & $1.0-6.0$ \\
\hline Cretian & 9 & 6.6 & $6.0-8.0$ \\
\hline Dark Green Zucchini & 12 & 5.4 & $2.0-7.0$ \\
\hline Dark Star & 12 & 4.8 & $4.0-6.0$ \\
\hline Dixie & 8 & 7.5 & $7.0-8.0$ \\
\hline Early Golden Summer Crookneck & 6 & 6.0 & $4.0-7.0$ \\
\hline Early Prolific Straightneck & 10 & 7.1 & $6.0-8.0$ \\
\hline Early Sugar & 6 & 4.8 & $1.0-7.0$ \\
\hline Early Sweet Sugar Pie & 12 & 7.1 & $6.0-8.0$ \\
\hline Early White Bush Scallop & 15 & 7.2 & $6.0-8.0$ \\
\hline Early Yellow Summer Crookneck & 11 & 8.0 & $7.0-8.0$ \\
\hline Eclipse & 12 & 5.4 & $5.0-6.0$ \\
\hline Eldorado & 12 & 5.1 & $4.0-6.0$ \\
\hline Fordhook Zucchini & 10 & 6.4 & $6.0-7.0$ \\
\hline Genie & 12 & 5.5 & $5.0-6.0$ \\
\hline
\end{tabular}

Table 4. (continued)

\begin{tabular}{|c|c|c|c|}
\hline Species and entry & $\mathrm{n}^{\mathrm{y}}$ & $\overline{\mathbf{x}}$ & Range \\
\hline Golden Bush Scallop & 9 & 7.9 & $7.0-8.0$ \\
\hline Golden Delicious & 11 & 6.8 & $6.0-8.0$ \\
\hline Golden Girl & 10 & 7.7 & $7.0-8.0$ \\
\hline Golden Nugget & 9 & 5.3 & $5.0-6.0$ \\
\hline Golden Summer Crookneck & 11 & 7.4 & $6.0-8.0$ \\
\hline Green Magic $F_{1}$ & 3 & 6.0 & $6.0-6.0$ \\
\hline Grey Zucchini & 20 & 6.2 & $4.0-8.0$ \\
\hline Half Moon & 11 & 7.4 & $6.0-8.0$ \\
\hline Jack-O-Lantern & 12 & 7.2 & $5.0-8.0$ \\
\hline Jersey Golden Acorn & 2 & 6.5 & $6.0-7.0$ \\
\hline Kindred & 20 & 6.9 & $5.0-9.0$ \\
\hline Lebanese & 12 & 6.5 & $5.0-8.0$ \\
\hline Lemon Drop & 11 & 7.5 & $7.0-8.0$ \\
\hline Poseidon & 7 & 3.7 & $1.0-6.0$ \\
\hline Ranger & 12 & 7.7 & $7.0-8.0$ \\
\hline Round Zucchini & 4 & 6.5 & $6.0-7.0$ \\
\hline Royal Acorn & 7 & 7.9 & $7.0-8.0$ \\
\hline Senator & 11 & $\therefore \quad 5.5$ & $4.0-6.0$ \\
\hline Slenderella & 8 & 7.6 & $7.0-8.0$ \\
\hline Slendergold & 10 & 7.7 & $7.0-8.0$ \\
\hline Small Sugar & 12 & 6.7 & $1.0-8.0$ \\
\hline Spirit & 12 & 6.6 & $6.0-8.0$ \\
\hline Spookie & 11 & 7.1 & $5.0-8.0$ \\
\hline Streaker & 10 & 5.9 & $1.0-8.0$ \\
\hline Summer Seneca Zucchini & 11 & 5.4 & $4.0-6.0$ \\
\hline Sunbeam & .11 & 7.0 & $6.0-8.0$ \\
\hline Suncake $F_{1}$ & 8 & 7.5 & $7.0-8.0$ \\
\hline Sunrise & 12 & 7.2 & $6.0-8.0$ \\
\hline Sweet Dumpling & 7 & 7.3 & $6.0-8.0$ \\
\hline Sweet Meat & 12 & 6.9 & $6.0-8.0$ \\
\hline Table Ace & 7 & 7.4 & $7.0-8.0$ \\
\hline Tableking Acorn & 2 & 7.0 & $7.0-7.0$ \\
\hline Tablequeen & 13 & 7.0 & $6.0-8.0$ \\
\hline Tara & 10 & 6.9 & $4.0-8.0$ \\
\hline Tatume & 12 & 6.0 & $1.0-7.0$ \\
\hline Unicorn & 10 & 5.8 & $2.0-7.0$ \\
\hline Vegetable Spaghetti & 13 & 6.3 & $4.0-7.0$ \\
\hline Vegetable Marrow White Bush & 12 & 6.8 & $6.0-8.0$ \\
\hline Winter Luxury & 4 & 7.0 & $6.0-8.0$ \\
\hline Zucchini Elite & 12 & 6.0 & $5.0-7.0$ \\
\hline
\end{tabular}

${ }^{2}$ Rated on a 1 (symptomless) to 9 (dead) scale.

${ }^{y}$ Total number of plants evaluated.

procedures in the respective tests. Plants in the field test had more whiteflies per plant that could freely feed on all plant parts, and they were continuously exposed to whitefly feeding.

The data suggest variation among the wild Cucurbita spp. for whitefly reproduction. Extreme pubescence or hirsute trichomes on the C. lundelliana accessions observed in this study (data not shown) could be an important factor. A dense covering of trichomes could provide a physical barrier between the egg and the epidermis. Indeed, we observed many eggs on $C$. lundelliarra to be suspended above the epidermis; these eggs were attached to the leaf by two waxy stilts at the thoracic region. In contrast, on leaves with few trichomes, the egg was attached to the epidermis all along the periphery.

We do not know whether such differences in reproduction would result in reduced incidence of SLC on squash or of other whitefly-transmitted viruses on other crops. In areas such as Imperial Valley, such a difference in survival might reduce incidence or severity of lettuce infectious yellows virus in lettuce because lettuce is planted $=1$ to 2 months after squash. This difference in planting dates is critical because whitefly populations can double in size every 10 days during" this period (But- 
Table 5. Squash leaf curl symptom ratings (mean and range) on wild or regionally important cucurbits in a naturally infected field test.'

\begin{tabular}{|c|c|c|c|}
\hline Species and collection & $\mathrm{n}^{\mathrm{y}}$ & $\overline{\mathrm{x}}$ & Range \\
\hline \multicolumn{4}{|l|}{ Benincasa hispida } \\
\hline var. Chieh-que & 6 & 1.0 & $1.0-1.0$ \\
\hline \multicolumn{4}{|l|}{ Cucurbita ficifolia } \\
\hline PI 540901 & 9 & 5.5 & $1.0-7.0$ \\
\hline Ibarra, Ecuador ${ }^{x}$ & 3 & 1.0 & $1.0-1.0$ \\
\hline Oaxaca, Mexico (black seed) ${ }^{\mathbf{x}}$ & 1 & 7.0 & $7.0-7.0$ \\
\hline \multicolumn{4}{|l|}{ Cucurbita foetidissima } \\
\hline Arizona synthetic $\# 1^{x}$ & 8 & 3.5 & $1.0-7.0$ \\
\hline PI 540902 & 11 & 4.6 & $3.0-6.0$ \\
\hline PI 540903 & 7 & 5.3 & $1.0-8.0$ \\
\hline \multicolumn{4}{|l|}{ Cucurbita texana } \\
\hline PI 540907 & 11 & 7.0 & $5.0-9.0$ \\
\hline \multicolumn{4}{|l|}{ Lagenaria siceraria } \\
\hline Cucuzzi & 10 & 1.0 & $1.0-1.0$ \\
\hline PI 540908 & 1 & 1.0 & $1.0-1.0$ \\
\hline PI 540909 & 5 & 1.0 & $1.0-1.0$ \\
\hline PI 540910 & 11 & 1.0 & $1.0-1.0$ \\
\hline PI 540911 & 9 & 3.2 & $1.0-6.0$ \\
\hline PI 540912 & 10 & 1.0 & $1.0-1.0$ \\
\hline PI 540913 & 12 & 1.0 & $1.0-1.0$ \\
\hline PI 540914 & 12 & 1.2 & $1.0-4.0$ \\
\hline PI 540915 & 12 & 1.0 & $1.0-1.0$ \\
\hline PI 540916 & 12 & 1.0 & $1.0-1.0$ \\
\hline PI 540917 & 8 & 1.0 & $1.0-1.0$ \\
\hline \multicolumn{4}{|l|}{ Luffa acutangula } \\
\hline PI 374214 & 9 & 1.0 & $1.0-1.0$ \\
\hline PI 540918 & 10 & 1.0 & $1.0-1.0$ \\
\hline PI 540919 & 6 & 1.0 & $1.0-1.0$ \\
\hline Luffa aegyptiaca & & & \\
\hline PI 271483 & 2 & 1.0 & $1.0-1.0$ \\
\hline \multicolumn{4}{|l|}{ Luffa graveolens } \\
\hline PI 540921 & 9 & 9.0 & $9.0-9.0$ \\
\hline
\end{tabular}

${ }^{2}$ Rated on a 1 (symptomless) to 9 (dead) scale.

Total number of plants evaluated in three replications.

${ }^{x}$ PI number pending.

ler et al., 1983, 1985; Gerling, 1967; Husain and Trehan, 1933; Zalom et al., 1985).

Development of SLC-resistant squash is a difficult challenge because of the number of species, problems of hybridization among the wild and cultivated Cucurbita, and because no one potential source of SLC resistance is obviously better than the others. Variation among plants of a given cultivar or wild accession suggest the possibility of some progress through selection and inbreeding within a given cultivar.

Among the four major cultivated species (maxima, mixta, moschata, and pepo), moschata has several sources of moderate, resistance to SLC and could be used as a source of resistance for pepo. The three wild species, ecuadorensis, lundelliana, and martinezii, are potential sources of resistance for the four major cultivated species. Curcurbita lundelliana has been used as abridge among the four major cultivated species and can be used as a bridge between ficifolia and the four major cultivated species (Esquinas-Alcazar and Gulick, 1983; Rhodes, 1959; Whitaker, 1959; Whitaker and Robinson, 1986).

\section{Literature Cited}

Azab, A. K., M.M. Megahed, and H.D. El-Mirsawi. 1970. On the range of host-plants of Bemisia tabaci (Germ.) Bul. Soc. Entomol. Egypte 55:305-315.

Bemis, W. P., J.W. Berry, C.W. Weber, and T.W. Whitaker. 1978. The buffalo gourd: A new potential horticultural crop. HortScience 13:235-240.

Butler, G. D., Jr., T.J. Hennebery, and T.E. Clayton. 1983. Bemisia tabaci (Homoptera: Aleyrodidae): Development, oviposition, and longevity in relation to temperature. Ann. Entomol. Soc. Amer. 76:310-313.

Butler, G. D., Jr., T.J. Hennebery, and E.T. NatWick. 1985. Bemisia tabaci: 1982 and 1983 populations in Arizona and California cotton fields. Southwestern Entomol. 10(1):20-25.

Cohen, S., J.E, Duffus, R.C. Larsen, H.Y. Liu, and R.A. Flock. 1984. Squash leaf curl virus-Purification, serology, and vector relationships of the whitefly transmitted geminivirus. Phytopathology 73:1669-1673.

Commonwealth Institute for Biological Control. 1981. Possibilities for the use of biotic agents in the control of the white fly, Bemisia tabaci. Biocontrol News \& Info. Dig. 2(1):1-7.

Esquinas-Alcazar, J.T. and P.J. Gulick. 1983. Genetic resources of cucurbitaceae —A global report. Intl. Board Plant Genet. Resources, Rome.

Flock, R.A. and D.E. Mayhew. 1981. Squash leaf curl, a new disease of cucurbits in California. Plant Dis. 65:75-76.

Gerling, D. 1967. Bionomics of the whitefly-parasite complex associated with cotton in southern California (Homoptera: Aleyrodidae; Hymenopteran: Aphelinidae). Ann. Entomol. Soc. Amer. 60:13061321.

Husain, M.A. and K.N. Trehan. 1933. Observations on the life-history, bionomics and control of the white-fly of cotton. Indian J. Agr. Sci. 3:701-753.

Kishaba, A. N., G.W. Bohn, and H.H. Toba. 1976. Genetic aspects of antibiosis to Aphis gossypii in Cucumis melo from India. J. Amer. Soc. Hort. Sci. 101:557-561.

Pollard, D.G. 1955. Feeding habits of the cotton whitefly, Bemisia tabaci Germ. (Homoptera: Aleyrodidae). Ann. Applied Biol. 43:664671.

Rhodes, A.M. 1959. Species hybridization and interspecific gene transfer in the genus Cucurbita. Plant Dis. Rpt. 48:54-55.

Toscano, N. C., J.A. Immaraju, and G.P. Georghiou. 1985. Resistance studies on the sweet potato whitefly Bemisia tabaci Germ. (Homoptera: Aleyrodidae) in the Imperial Valley, California, Proc. Cotton Insect and Production Meeting, 1985, California Coop. Ext., Univ. of California and Colorado River Cotton Growers Assn. p. 14-16.

Varma, P.M. 1963. Transmission of plant viruses by whiteflies. Bul. Natl. Inst. Sci. India 24:11-33.

Ward, G.M. 1973. Calcium deficiency symptoms in greenhouse cucumbers. Can. J. Plant Sci. 53:849-856.

Whitaker, T.W. 1959. An interspecific cross in Cucurbita (C. lundelliana) Bailey $\times$ C. moschata). Madroño 15:4-13.

Whitaker, T.W. and G.N. Davis. 1962. Cucurbits. InterScience, New York.

Whitaker, T.W. and R.W. Robinson. 1986. Squash breeding, p. 209242. In: M.J. Bassett (cd.). Breeding vegetable crops. AVI, Westport, Corm.

Zalom, F. G., E.T. NatWick, and N.C. Toscano. 1985. Temperature regulation of Bemisia tabaci (Homoptera: Aleyrodidae) populations in Imperial Valley cotton. J. Econ. Entomol. 78:61-64. 